\title{
Maternal Mortality Rate at East Ogan Komering Ulu (East OKU) Regional Public Hospital Over a Four Year Period: Trends, Its Associated Factors and Neonatal Outcome
}

\author{
Angka Kematian Ibu di RSUD Ogan Komering Ulu Timur (OKU Timur) dalam Periode \\ Empat Tahun : Pola, Faktor yang Berkaitan dan Luaran Neonatus
}

\author{
Cindy Kesty, Hendra S Saputra
}

East Ogan Komering Ulu (East OKU)

Regional Public Hospital, Sumatera Selatan

\begin{abstract}
Objective : To determine the MMR trends, its associated factors, and neonatal outcome at East Ogan Komering Ulu Regional Public Hospital from 2013 until 2016.

Methods : This descriptive study was performed from January 2013 until December 2016 in maternity ward and Intensive Care Unit (ICU) of East Ogan Komering Ulu Regional Public Hospital, South Sumatera. Data were collected from medical records. There were 17 maternal deaths, but one was excluded due to lack of data.

Results : We recorded 2,191 pregnancies and 17 maternal deaths. Over four years, the lowest MMR occurred in 2013 $(229 / 100,000)$ and achieved its peak in 2014 (1,306/100,000). Then, MMR followed a downward trend dropping from $1,087 / 100,000$ in 2015 until 588/100,000 in 2016. Most of the deceased were childbearing age women (50.0\%), multigravida (62.5\%), but nulliparous (50.0\%), and aterm (87.5\%). The major aetiology of maternal deaths were hypertensive disorders (37.5\%), followed by hypertensive disorders combined with haemorrhage and hypertensive disorders combined with infection in the same proportion. MMR was higher in inborn cases (87.5\%), born via C-section $(87.5 \%)$, and treated for less than 48 hours (93.75\%). Alive neonatal were born in most cases (62.5\%).
\end{abstract}

Conclusions: MMR trends in our hospital were fluctuating with a downward trend, but still much higher than the MDGs target in 2015 (102/100,000). Hypertensive disorder plays a significant role in maternal deaths. In addition, most of the neonates were born alive. We hope that this study can be feedback for the hospital to do maternal and perinatal audit.

Keywords : factors, maternal mortality rate, neonatal outcome, regional public hospital, trends

\begin{abstract}
Abstrak
Tujuan : Untuk menentukan pola, faktor yang berkaitan, dan luaran neonatus di RSUD Ogan Komering Ulu Timur dari 2013 hingga 2016.
\end{abstract}

Metode : Studi deskriptif dilakukan dari Januari 2013 hingga Desember 2016 di bangsal kebidanan dan unit perawatan intensif RSUD Ogan Komering Ulu Timur, Sumatera Selatan. Data dikumpulkan dari rekam medik. Terdapat 17 kematian ibu, tetapi 1 data dieksklusi karena data yang kurang lengkap.

Hasil : Terdapat 2.191 kehamilan, dan 17 kematian ibu. Selama 4 tahun, AKI terendah terjadi pada 2013 (229/100.000) dan mencapai puncaknya pada 2014 (1.306/100.000). Kemudian, AKI mengalami penurunan dari 1.087/100.000 pada 2015 hingga 588/100.000 pada 2016. Mayoritas sampel berusia reproduktif $(50,0 \%)$, multigravida $(62,5 \%)$ dan nulipara $(50,0 \%)$, serta aterm $(87,5 \%)$. Mayoritas kematian ibu disebabkan oleh hipertensi dalam kehamilan (HDK) $(37,5 \%)$, diikuti oleh HDK + perdarahan dan HDK + infeksi dalam jumlah yang sama. AKI lebih tinggi pada ibu yang melahirkan di RS (87,5\%), melahirkan melalui seksio sesarea (87,5\%), dan dirawat selama kurang dari 48 jam (93,75\%). Mayoritas neonatus dilahirkan hidup (62,5\%).

Kesimpulan : Pola AKI di RSUD berfluktuasi dengan pola menurun, tetapi masih jauh lebih tinggi dari target MDGs pada tahun 2015 (102/100,000). Hipertensi dalam kehamilan berperan signifikan terhadap kematian ibu. Mayoritas neonatus dilahirkan hidup. Studi ini diharapkan dapat menjadi masukan bagi rumah sakit untuk melakukan audit maternal dan perinatal.

Kata kunci : angka kematian ibu, faktor, luaran neonatus, pola, rumah sakit umum daerah 


\section{INTRODUCTION}

One of the Millenium Developmental Goals (MDGs) 2015 was improving maternal health with two specific targets and six indicators. Firstly, reducing Maternal Mortality Rate (MMR) by $3 / 4$ between 1990 and 2015. Secondly, achieving universal access to reproductive health. MMR was one of the indicators for predicting maternal health status. It was determined from the number of maternal deaths (during pregnancy, childbirth, or within 42 days of termination of pregnancy) during a given period per 100,000 live births during the same period. ${ }^{1-4}$

Maternal deaths were defined by $\mathrm{WHO}$ as the death of a woman while pregnant or within 42 days of termination of pregnancy, irrespective of the duration and site of the pregnancy, from any cause related to or aggravated by pregnancy and its management, but not from accidental or incidental causes. Direct cause of MMR accounted for about 75-80 percent, consisting of hemorrhage (25.0\%), infection/sepsis (15.0\%), eclampsia (12.0\%), unsafe abortion (13.0\%), obstructed and/or prolonged labor (8.0\%), and other $(8.0 \%))^{1,3,5-9}$

Overall,South-EastAsia had moderate mortality with moderate access, but Indonesia was one of the countries with high MMR in South-East Asia. ${ }^{6}$ Therefore, the government took several strategic implementations for reducing MMR faster by taking clinical intervention and improving health access. ${ }^{3,4}$ In 1987, safe motherhood initiative (ensuring all women got the appropriate treatment so that they could be safe and healthy during pregnancy and childbirth) was launched by WHO and other groups. ${ }^{4,5}$ Then, in 1996, the government launched "Gerakan Sayang Ibu" programme which involved all governmental sectors. In 2000, the Ministry of Health launched Making Pregnancy Safer strategy. ${ }^{4}$

According to data from the Indonesian Demographic and Health Survey (SKDI) in 2012, MMR increased from 228 to 359 deaths per 100,000 live births. It was still far from MDGs 2015 target (102 deaths per 100,000 live births). Because of that, comprehensive-strategic interventions involving the government and society must be done in order to achieve that target. One of them was Expanding Maternal and Neonatal Survival
(EMAS) programme which was launched by the Ministry of Health for decreasing MMR and NMR by $25 \% .{ }^{4}$

In order to determine the magnitude of and trends in MMR, its associated factors, and neonatal outcome, we are motivated to conduct a study about MMR at East OKU Regional Public Hospital from 2013 until 2016.

\section{METHODS}

This descriptive study was performed from January 2013 until December 2016 in the maternity ward and Intensive Care Unit (ICU) of East OKU Regional Public Hospital, South Sumatera. Data were collected from medical records. All maternal deaths caused by pregnancy and its management were included in this study. Over four years period, there were 17 maternal deaths, but one was excluded when we analysed the maternal and neonatal variables due to lack of data. The total live birth during the corresponding year was also recorded. We described several maternal variables, such as age, gravida, parity, gestational age, diagnosis, delivery location, delivery method, and length of stay. In addition, only one neonatal variable was described, namely neonatal outcome. Then, all data were studied and analysed using Stata/MP 13.0.

\section{RESULTS}

The total number maternal deaths in 2013, 2014, 2015 and 2016 were 1, 7, 4, 5 corresponding to the total number of live births of $436,536,368$, and 851 respectively. Over four years period, the lowest MMR occurred in $2013(229 / 100,000)$ and reached its peak in $2014(1,306 / 100,000)$. Then, MMR followed a downward trend dropping from 1,087/100,000 in 2015 until 588/100,000 in 2016. Hence, the mean of MMR during those years were $802.5 / 100,000$ live births. (See figure 1)

In table 1 , there were eight maternal variables described. The highest risk of MMR was among childbearing age women: $20-35$ years old (50.0\%) with the mean age of 29.9 years old. Moreover, most of them were multigravida (62.5\%), but nulliparous (50.0\%), and aterm: $37-42$ weeks (87.5\%). The major direct aetiology of maternal deaths were hypertensive disorders (37.5\%), followed by hypertensive disorders combined 
with haemorrhage and hypertensive disorder + infection in the same proportion (12.5\%). The other five classifications, such as hypertensive disorder + obstructed labour, haemorrhage, hypertensive disorder + haemorrhage + infection, obstructed labour, obstructed labour + haemorrhage also had the same proportion (6.25\%). The indirect aetiology found in our cases was acute myocardial infarct (6.25\%).

Maternal deaths were higher in those who bore via C-section (87.5\%) and inborn cases (87.5\%). As much as 15 maternal deaths (93.75\%) occurred within 48 hours of admission. From table 2, we could see that most neonates were born alive (62.5\%).

Table 1. Maternal Variables of Maternal Mortality Rate

2013201420152016 Total (\%)

\begin{tabular}{|c|c|c|c|c|c|c|}
\hline \multicolumn{7}{|l|}{ Age } \\
\hline$<20$ & 0 & 1 & 1 & 0 & 2 & (12.5) \\
\hline 20-35 & 0 & 5 & 1 & 2 & 8 & (50.0) \\
\hline$>35$ & 1 & 1 & 1 & 3 & 6 & (37.5) \\
\hline \multicolumn{7}{|l|}{ Gravida } \\
\hline Primigravida & 0 & 3 & 2 & 1 & 6 & (37.5) \\
\hline Multigravida & 1 & 4 & 1 & 4 & & $(62.5)$ \\
\hline \multicolumn{7}{|l|}{ Parity } \\
\hline Nulliparous & 0 & 4 & 3 & 1 & 8 & $(50.0)$ \\
\hline Primiparous & 0 & 1 & 0 & 3 & 4 & $(25.0)$ \\
\hline Multiparous & 1 & 2 & 0 & 1 & 4 & $(25.0)$ \\
\hline Grandemultiparous & 0 & 0 & 0 & 0 & 0 & $(0.0)$ \\
\hline \multicolumn{7}{|l|}{ Gestational Age } \\
\hline$<37$ weeks & 0 & 0 & 1 & 1 & 2 & $(12.5)$ \\
\hline 37- 42 weeks & 1 & 7 & 2 & 4 & 14 & $(87.5)$ \\
\hline > 42 weeks & 0 & 0 & 0 & 0 & 0 & $(0.0)$ \\
\hline \multicolumn{7}{|l|}{ Diagnosis } \\
\hline$H D$ & 0 & 2 & 2 & 2 & 6 & (37.5) \\
\hline $\mathrm{HD}+\mathrm{H}$ & 0 & 2 & 0 & 0 & 2 & $(12.5)$ \\
\hline$H D+I$ & 0 & 1 & 1 & 0 & 2 & (12.5) \\
\hline $\mathrm{HD}+\mathrm{OL}$ & 1 & 0 & 0 & 0 & 1 & $(6.25)$ \\
\hline $\mathrm{H}$ & 0 & 0 & 0 & 1 & 1 & $(6.25)$ \\
\hline $\mathrm{HD}+\mathrm{H}+\mathrm{I}$ & 0 & 1 & 0 & 0 & 1 & $(6.25)$ \\
\hline $\mathrm{OL}$ & 0 & 0 & 0 & 1 & 1 & $(6.25)$ \\
\hline $\mathrm{OL}+\mathrm{H}$ & 0 & 1 & 0 & 0 & 1 & $(6.25)$ \\
\hline Others (Acute & 0 & 0 & 0 & 1 & 1 & $(6.25)$ \\
\hline \multicolumn{7}{|l|}{ Myocardial Infarct) } \\
\hline \multicolumn{7}{|l|}{ Delivery Location } \\
\hline Unborn & 0 & 0 & 0 & 1 & 1 & $(6.25)$ \\
\hline Inborn & 1 & 7 & 3 & 3 & & $(87.5)$ \\
\hline Outborn & 0 & 0 & 0 & 1 & 1 & (6.25) \\
\hline \multicolumn{7}{|l|}{ Delivery Method } \\
\hline Unborn & 0 & 0 & 0 & 1 & 1 & $(6.25)$ \\
\hline Spontaneous & 0 & 0 & 0 & 1 & 1 & (6.25) \\
\hline C-Section & 1 & 7 & 3 & 3 & & $(87.5)$ \\
\hline \multicolumn{7}{|l|}{ Length of Stay } \\
\hline$<48$ hours & 1 & 6 & 3 & 5 & 15 & (93.75) \\
\hline$>48$ hours & 0 & 1 & 0 & 0 & 1 & $(6.25)$ \\
\hline
\end{tabular}

\section{Note:}

HD : Hypertensive Disorders I : Infection

$\mathrm{H}$ : Hemorrhage
Table 2. Neonatal Variables of Maternal Mortality Rate

2013201420152016 Total (\%)

\begin{tabular}{lllllr}
\hline Neonatal Outcome & & & & & \\
Alive & 1 & 5 & 2 & 2 & $10(62.5)$ \\
Died & 0 & 2 & 1 & 3 & $6(37.5)$ \\
\hline
\end{tabular}

\section{DISCUSSION}

ur study showed that the mean of MMR in our hospital from 2013 until 2016 was about eight times higher than the MDGs target. This fluctuating MMR trends indicated a dynamic process probably associated with certain precipitating factors. ${ }^{7}$ There were three delays which might correlate with high MMR. Firstly, delays in recognising an emergent situation and/ or seeking care to health practitioners. Secondly, delays in reaching appropriate care due to lack of access to transport or resources to pay for transport. Thirdly, delays in receiving appropriate care, including adequate quality of care, after arrival at a health facility. ${ }^{5}$

Childbearing age women were the greatest risk for maternal mortality in our hospital. In the age group $<20$ years and $>35$ years, there were $2(12.5 \%)$ and 6 (37.5\%) cases respectively. This was different from a previous study by Ujah IAO, et al (2005) which stated that the highest risk of maternal mortality was among early teenagers and older women. ${ }^{7}$ The difference was probably because of the difference in sociodemographic characteristic. Moreover, we only analysed 4 years period, compared with 17 years period done by Ujah IAO, et al.

We found that nulliparous was the most common group with high MMR, followed by primiparous and multiparous in the same proportion. Based on gravida criteria, most of the deceased were multigravida (62.5\%). This study revealed that most women had abortion history, but no women died because of abortion. In contrast, historical trends in England and Wales from 1872-1876 and 1976-1981 showed that a small percentage (4.0-8.0\%) of women died from abortion. ${ }^{10}$

During 2013-2016, our study revealed that direct cause plays a significant role in most cases of maternal death. This is similar to a previous study by Chakraborty S. and Kassebaum NJ..$^{1,8,11}$ The major direct causes of MMR in our 
hospital were hypertensive disorder followed by hypertensive disorder + hemorrhage and hypertensive disorder + infection.

The largest proportion of maternal mortality in our study was those bore in health care facilities where the aetiology could be treated more comprehensively. This group delivered their babies by caesarean section due to their underlying medical conditions. This correlated with the previous study by Bauserman, $M$, et al who presumed that women were delivered by caesarean section due to the condition that put them in higher risks of death. ${ }^{11,12}$

Fifteen maternal deaths (93.75\%) occurred within 48 hours of admission. This implied that most women came to seek medical care when their condition had already became serious. ${ }^{7}$ Maternal death increased the risk of perinatal and neonatal death. However, in our study, we found that most of the neonates were born alive (62.5\%). This difference was because we did not follow up the neonates prospectively.

The limitation of our study was that we did not record other factors which might contribute to MMR. For instance, education level, economic status, maternal nutritional status, antenatal care (ANC), timing of referral, access to health care, etc. Incomplete and manual medical record also limited us to conduct a thorough analysis regarding MMR. Through this study, we hoped that annual maternal and perinatal audits could be done.

\section{CONCLUSION}

MMR trends in our hospital were fluctuating with a downward trend and reaching its peak in 2014. It was still much higher than the MDGs target in $2015(102 / 100,000)$. Because of that, Expanding Maternal and Neonatal Survival (EMAS) programme which was launched by the Ministry of Health must be reviewed and wellimplemented in all over Indonesia, especially East OKU.

Direct cause plays a significant role in maternal deaths. Hypertensive disorder had the biggest proportion in our study. In addition, most of the neonates were born alive. Further analysis and complete medical records are needed in order to investigate the risk factors. We hope that this study can be feedback for the hospital to do maternal and perinatal audit

\section{REFERENCES}

1. Chakraborty S. and Sebanti G. Maternal Mortality Rate and Its Causes - Changing Trends in Kolkata, India. IJRRMS. 2012; 2(1): 16-8.

2. World Health Organization. Trends in Maternal Mortality: 1990 to 2015 Estimates by WHO, UNICEF, UNFPA, World Bank Group and the United Nations Population Division. 2015; i-77.

3. Joe W, Sharma S, Sharma J, Shanta YM, Ramanathan M, Mishra US, et al. Maternal Mortality in India: A Review of Trends and Patterns. IEG Working Paper. 2015; 353: 3-26.

4. Primadi $O$, Yudianto, Budijanto D, Hardhana B, Soenardi TA, et al. Profil Kesehatan Indonesia 2014. Jakarta: Kementerian Kesehatan Republik Indonesia. 2015; 98101.

5. Nieburg P. Improving Maternal Mortality and Other Aspects of Women's Health: The United States' Global Role. Washington DC: Center for Strategic and International Studies. 2012; 1-21.

6. United Nations. Millennium Development Goals: Progress Chart. 2015

7. Ujah IAO, Aisien OA, Mutihir JT, Vanderjagt DJ, Glew $\mathrm{RH}$, and Uguru VE. Factor Contributing to Maternal Mortality in North-Central Nigeria: A Seventeen-year Review. Afr J Reprod Health. 2005; 9(3): 27-40.

8. Kassebaum, NJ. Global, Regional, and National Levels of Maternal Mortality, 1990-2015: A Systematic Analysis for the Global Burden of Disease Study 2015.Lancet 2016; 388: 1775-812.

9. Datta D. and Datta PP. Maternal Mortality in India: Problems and Strategies. Asian J Med Res. 2013; 2(2): 33-5.

10. Loudon, I. Maternal Mortality in The Past and Its Relevance to Developing Countries Today. Am J Clin Nutr. 2000;72 (suppl):241S-6S.

11. Bauserman $M$, Lokangaka $A$, Thorsten $V$, Tshefu A, Goudar SS, Esamai F, et al. Risk Factors for Maternal Death and Trends in Maternal Mortality in Low- and Middle-Income Countries: A Prospective Longitudinal Cohort Analysis. Reprod Health. 2015, 12(Suppl 2):S5.

12. Saleem S, McClure EM, Goudar SS, Patel A, Esamai F, Garces A, et al. A Prospective Study of Maternal, Fetal, and Neonatal Deaths in Low- and Middle-Income Countries. Bull World Health Organ. 2014 ; 92(8): 60512. 